Sharif University of Technology
Scientia Iranica
Transactions E: Industrial Engineering
h.tp://scientiairanica.sharif.edu
IRAN I CA

\title{
Designing a bi-objective rice supply chain considering environmental impacts under uncertainty
}

\author{
M.J. Kazemi, M.M. Paydar*, and A.S. Safaei \\ Department of Industrial Engineering, Babol Noshirvani University of Technology, Babol, Iran.
}

Received 11 May 2020; received in revised form 9 November 2020; accepted 4 January 2021

\section{KEYWORDS}

Agricultural supply

chain;

Rice supply chain;

Uncertainty;

Extended goal

programming;

Sensitivity analyses.

\begin{abstract}
Rice is a strategic commodity in the food chain for the people and governments. It is a fundamental food for many societies. Moreover, producing rice can provide a reliable source of revenue if proper supply chain management is coordinated by farmer countries. The rice supply chain includes diverse elements such as farms, rice mills, distribution centers, and markets. This study examines the important factors that play a significant role in the rice supply chain. A bi-objective mathematical model is formulated to minimize total costs as an economic goal and minimize soil erosion and its destruction due to the consumed water for rice cultivation as an environmental goal. To verify the viability of the proposed model, a case study of the rice supply chain with limited producer farms has been investigated. Moreover, some parameters such as annual precipitation in production areas along with other factors are presented under several scenarios. Furthermore, an extended goal programming approach and stochastic programming are utilized to solve the proposed model. Finally, the sensitivity analyses of the important parameters have been performed.
\end{abstract}

(C) 2023 Sharif University of Technology. All rights reserved.

\section{Introduction}

Agriculture is one of the most important sectors of the economy in every country that plays a significant role in its political, economic, and social independence. The lack of a comprehensive information system and a functional model in the supply chain of agricultural products has made this sector of the country's economy, despite potential talent, ineffective [1]. Considering the importance of the agricultural sector in society, providing a share of $13 \%$ of the society's food demand increases the need for an integrated supply chain study in the agricultural sector [2]. Moreover, $10 \%$

*. Corresponding author.

E-mail addresses: mohammadjalal5400@yahoo.com (M.J.

Kazemi); paydar@nit.ac.ir (M.M.Paydar);

s.safaei@nit.ac.ir (A.S.Safaei)

doi: $10.24200 /$ sci. 2021.55935 .4481 of the share of raw materials required by the food industry, $11 \%$ of the agricultural sector in the gross national product, $22 \%$ of the share of employment in the country, and $23 \%$ non-oil exports proves the importance of this matter. Sustainable agriculture is a system that improves the quality of the environment and natural resources through proper management and use of resources to meet human food needs [3]. Rice is one of the most consumed products in the commodity market, and its strategic role in the economy of the countries and the intense involvement of environmental agents for its cultivation have made it an important commodity. It is imperative to pay attention to the type of supply and distribution as well as the proper design of the supply chain for the countries that have this product. The rice supply chain is a part of the agricultural supply chain that evaluates its life cycle and economic aspects, as well. The proposed model employed in this study seeks to answer the following questions: 
- What is the amount of optimal unhusked rice production in terms of costs, demand, and environmental factors in each producer region?

- How much rice should be produced to meet the demand of the country?

- How much rice is directly delivered to the market and how much is distributed through distribution centers?

- What is the actual demand of the country to import rice?

- How much water should be used to produce rice to minimize environmental damage?

- What is the optimal number of farms needed for rice cultivation?

For this purpose, a bi-objective linear mathematical model with the economic and environmental objectives is designed for the rice supply chain that analyzes the responses with an extended goal programming approach. Moreover, a case study is carried out on rice supply with four main producers and an examination of rice imports to meet demand and current costs in the rice chain. Furthermore, the used resources and the environmental damage due to water consumption for rice cultivation in this chain are considered. Besides, some parameters such as annual precipitation in production areas along with other factors are presented under several scenarios. Also, an extended goal programming approach and stochastic programming are utilized to solve the proposed model. Finally, the sensitivity analyses of the important parameters have been performed.

In the next section, a review of studies in the field of the agricultural supply chain is investigated. Section 3 presents the proposed mathematical model. Section 4 describes the solution method. In Section 5, a description of the proposed case study and sensitivity analyses of the key parameters of the model are provided. Section 6 considers the managerial insights of the research.

\section{Literature review}

The supply chain involves coordinating and integrating key activities that start from the purchase of raw materials to the distribution of final products to customers $[4,5]$. The agricultural supply chain is one of the most important areas that has been considered in recent years and a significant improvement in its optimization is reported [6]. Agriculture includes a wide range of problems such as cultivations, gardening, tree planting, and vegetable planting along with livestock management issues [7]. Nowadays, agriculture management is essential from two perspectives: responding to the growing demand of today's society and balancing production and harvest. Besides, responding to the needs of the current community may endanger the needs of the future community [8]. The main components of the agricultural and rice supply chain are listed below [9]:

1. Production and storage of agricultural products;

2. Processing of products in rice mills;

3. Distribution of agricultural products from the rice mill to wholesalers or distribution centers;

4. Delivery of final products to customers.

Operations research attempts to solve agricultural management problems that were empirically and traditionally entrusted with verbal judgments $[10,11]$. Similarly, uncertainty in the supply chain or particular parts of it, as one of the key elements of this chain, is raised as an important issue to consider and this consideration brings the problem closer to reality. Uncertainty is one of the most important factors in the agricultural supply chain, which can be related to production volume, weather conditions, soil quality and seasonal factors, and availability of resources and capital [12].

Various sectors of agriculture include management, tactics, and operations that have been modeled by operational research techniques since 1940 . However, the concept of uncertainty over the past two decades shows that it is helpful to explore operations to solve its problems [13-15]. Appropriate modeling for utilizing incomplete data is made possible using various uncertainty techniques. These techniques are used to deal with uncertain data such as stochastic programming, robust programming, and simulationbased programming. Meanwhile, the food industry is highly attentive to uncertainty among all the agricultural supply chain sectors [16]. One of the earliest researches on the supply chain of agricultural products was proposed by Sorensen and Gilheany [17]. In their research, several factors such as type of transportation and sugarcane harvesting strategy under various atmospheric conditions and rainfall were considered. Arnaout and Maatouk [18] proposed a study on harvest planning and their mathematical model was an attempt to minimize the costs of transportation, harvesting, and construction of a processing location. Gorton et al. [19] studied the environmental factors in the agricultural sector. They investigated fresh vegetables and fruits and examined important factors such as government policy on production or non-production and the magnitude impact of agricultural production on environmental resources. Badrul et al. [20] examined the water consumption in a Canadian region and measured its impact on barley crop growth. Moreover, they considered the effect of water during crop cultivation and the extent of damage to the soil, and the use of energy sources to extract water from underground 
aquifers is considered as its main goals. In this research, the annual rainfall and other water requirements for barley cultivation are predicted under uncertainty.

In recent years, an agricultural supply chain has faced different and conflicting objectives that request the chain to be more sustainable. Sustainable supply chain management seeks a strategic integration of economic, environmental, and social considerations. This approach helps managers design survival strategies and achieve the success of the organization on a long-term horizon. This may provide a comprehensive perspective for the supply chain process and include technologies such as delivery, cost, control, and inventory [21]. Sepehri and Sazvar [22] provided a study on supply chain sustainability. In this regard, they examined a mathematical model for deteriorating and seasonal products to balance environmental, economic, and social criteria. Jafari et al. [23] studied a sustainable supply chain model in the textile industry. One of the most important goals has been to consider minimizing the negative effects of wasteful extraction of groundwater use in the industry. Reidsma et al. [24] performed a comprehensive review of the articles on the sustainability of agricultural supply chains. By adapting to their work, it can be found that among the three goals presented in the sustainable agricultural supply chain, the role of the economic target is greater than those of the environmental and social goals. Correspondingly, among the economic goals, the largest share is associated with costs minimization and profit maximization. Usually, some repetitious factors such as product sales prices, transportation costs, and maintenance costs are involved. Furthermore, the number of used resources and the amount of water produced and consumed under uncertain conditions are more frequent among the objectives of the environmental impact. Stochastic programming is the most adopted technique in facing uncertainty. Mohammadi et al. [25] presented a model with three objectives: to maximize profits, minimize environmental impacts, and maximize social benefits. The $\varepsilon$-constraint and path-formulation methods were adopted for handling the multi-objective and stochastic nature of the problem. Sazvar et al. [26] examined a sustainable supply chain problem for the product that is made with several production methods. The three optimized aspects of the sustainable supply chain consist of minimizing costs and environmental degradation and maximizing the consumer health levels. Mogale et al. [27] examined a bi-objective supply chain model for harvesting agricultural products in India. In the model, the objective is to minimize costs and carbon dioxide emission. The meta-heuristic algorithms are used to solve the model.

Yamchi et al. [28] presented a bi-level model in the agricultural supply chain. The levels of this model are the optimization of the workflow at all levels and sustainability in the supply chain. This sustainability includes goals such as minimizing carbon dioxide emissions and costs as well as maximizing responsiveness. Deterministic data was used in the mentioned work. Motevalli-Taher et al. [29] provided a sustainable supply chain for wheat and its products. In the research, such goals as minimizing network costs and water consumption and maximizing job opportunities were mentioned. Jia et al. [30] provided a tri-objective model that included minimizing environmental, economic and energy risks. The application of this model has been demonstrated by a case study in the Persian Gulf countries.

\subsection{Innovations and research gaps}

Seriously, a very limited number of works done in the field of the agricultural supply chain addressed the issue of soil loss due to adverse water use. As is known, the soil is one of the most important components of agriculture. At the same time, unfortunately, researchers consider it as a permanent member of their work, and we rarely see this issue. In the present work, minimizing the environmental impact function can be interpreted in two ways. Frequently performed functions in agricultural chains often examined economic characteristics, which is also addressed in the present work. The first case is the minimization or, in other words, optimization of water consumption, which can be achieved in two ways. In the second case, following the mentioned minimization, the amount of damage to the soil was minimized. This importance is implicitly extracted from this model. A brief review of the recent studies in the field of the agricultural supply chain is performed to show the novelty of the current research. As shown in Table 1, each research is presented separately by various criteria such as objectives, data, and solution methods. In terms of objectives, it is clear that most of the studies have focused on the economic dimension of the supply chain as maximizing profits or minimizing costs. The second important objective in this chain is to investigate the environmental impacts of pollution, resource or waste utilization, irrigation, and other influential factors. As indicated in Table 1, the proposed rice study chain includes two important objective functions that consist of minimizing costs and water consumption in farms. The main reported costs are listed as transportation costs, plant costs, import costs, and agricultural costs.

Water used for rice cultivation is considered as surface water and rainfall, which has not been reported in previous works, to the best of our knowledge. Within diverse products of the food chain, rice production is studied in the current case study, which has not been addressed in previous researches. Moreover, the proposed model is solved by an extended goal programming approach. Stochastic 
Table 1. A brief review of related researches.

\begin{tabular}{|c|c|c|c|c|c|c|}
\hline \multirow{2}{*}{ Researcher } & \multirow{2}{*}{$\begin{array}{l}\text { Type of } \\
\text { problem }\end{array}$} & \multicolumn{2}{|r|}{ Objective function } & \multirow{2}{*}{$\begin{array}{l}\text { Case } \\
\text { study }\end{array}$} & \multirow{2}{*}{ Data } & \multirow{2}{*}{$\begin{array}{l}\text { Solution } \\
\text { approach }\end{array}$} \\
\hline & & Type & Description & & & \\
\hline Chen et al. [35] & $\begin{array}{l}\text { Harvest } \\
\text { planning }\end{array}$ & $\mathrm{SO}$ & $\downarrow$ Costs & - & Uncertain & Heuristic \\
\hline $\begin{array}{l}\text { Etemadnia } \\
\text { et al. [36] }\end{array}$ & $\begin{array}{l}\text { Fruit } \\
\text { planning }\end{array}$ & $\mathrm{BO}$ & $\begin{array}{l}\uparrow \text { Profit, } \\
\downarrow \text { Environmental impacts }\end{array}$ & $\begin{array}{l}\text { Fruits and } \\
\text { vegetables }\end{array}$ & Deterministic & $\begin{array}{l}\text { Mixed-integer } \\
\text { linear programming }\end{array}$ \\
\hline $\begin{array}{l}\text { Hajikhani } \\
\text { et al. [37] }\end{array}$ & Urban-Agri & $\mathrm{MO}$ & $\begin{array}{l}\downarrow \text { Costs, } \\
\downarrow \text { Delay, } \\
\uparrow \text { Covering }\end{array}$ & - & Uncertain & $\begin{array}{l}\text { Fuzzy logic, } \\
\text { weighted sum, } \\
\text { meta-heuristics }\end{array}$ \\
\hline $\begin{array}{l}\text { Catalá } \\
\text { et al. [38] }\end{array}$ & $\begin{array}{l}\text { Fruit } \\
\text { planning }\end{array}$ & $\mathrm{BO}$ & $\begin{array}{l}\uparrow \text { Production, } \\
\downarrow \text { Environmental impacts }\end{array}$ & Fruit & Uncertain & $\begin{array}{l}\text { An innovative } \\
\text { method using } \\
\text { integer programming }\end{array}$ \\
\hline $\begin{array}{l}\text { Martín } \\
\text { et al. [39] }\end{array}$ & $\begin{array}{l}\text { Harvest } \\
\text { planning }\end{array}$ & MO & $\begin{array}{l}\downarrow \text { Costs, } \\
\uparrow \text { Production, } \\
\text { choosing the location }\end{array}$ & Wheat & Deterministic & $\varepsilon$-constraint \\
\hline $\begin{array}{l}\text { Gomes } \\
\text { et al. [40] }\end{array}$ & Foodstuffs & $\mathrm{BO}$ & $\begin{array}{l}\uparrow \text { Profit, } \\
\downarrow \text { Environmental impacts }\end{array}$ & - & Deterministic & $\begin{array}{l}\text { Mixed-integer linear } \\
\text { programming }\end{array}$ \\
\hline $\begin{array}{l}\text { Soto-silva } \\
\text { et al. [41] }\end{array}$ & $\begin{array}{l}\text { Fruit } \\
\text { planning }\end{array}$ & $\mathrm{BO}$ & $\begin{array}{l}\uparrow \text { Profit, } \\
\downarrow \text { Environmental effects }\end{array}$ & Apple & Deterministic & Heuristic \\
\hline $\begin{array}{l}\text { Tian } \\
\text { et al. [42] }\end{array}$ & $\begin{array}{l}\text { Harvest } \\
\text { planning }\end{array}$ & MO & $\begin{array}{l}\uparrow \text { Profit, } \\
\uparrow \text { Production, } \\
\downarrow \text { Environmental impacts }\end{array}$ & Wheat & Uncertain & Weighted sum \\
\hline $\begin{array}{l}\text { Cheraghalipour } \\
\text { et al. [43] }\end{array}$ & Citrus & $\mathrm{BO}$ & $\begin{array}{l}\downarrow \text { Costs, } \\
\uparrow \text { Accountability }\end{array}$ & Orange & Deterministic & $\begin{array}{l}\text { Goal programming, } \\
\varepsilon \text {-constraint }\end{array}$ \\
\hline $\begin{array}{l}\text { Chávez } \\
\text { et al. [44] }\end{array}$ & Citrus & $\mathrm{MO}$ & $\begin{array}{l}\uparrow \mathrm{NPV}, \\
\downarrow \text { Environmental impacts } \\
\uparrow \text { Social impacts }\end{array}$ & Coffee & Deterministic & $\varepsilon$-constraint \\
\hline $\begin{array}{l}\text { Allaoui } \\
\text { et al. [45] }\end{array}$ & Food & $\mathrm{MO}$ & $\begin{array}{l}\downarrow \text { Social implication, } \\
\downarrow \text { Environmental impact, } \\
\downarrow \text { Costs }\end{array}$ & - & Deterministic & Heuristic \\
\hline $\begin{array}{l}\text { Bergendahl } \\
\text { et al. [46] }\end{array}$ & $\begin{array}{l}\text { Food and } \\
\text { water }\end{array}$ & $\mathrm{SO}$ & $\downarrow$ Environmental impacts & - & Deterministic & $\begin{array}{l}\text { Mathematical } \\
\text { programming }\end{array}$ \\
\hline $\begin{array}{l}\text { Cheraghalipour } \\
\text { et al. [47] }\end{array}$ & $\begin{array}{l}\text { Harvest } \\
\text { planning }\end{array}$ & $\mathrm{BP}$ & $\begin{array}{l}\downarrow \text { Farm costs, } \\
\downarrow \text { Factory costs }\end{array}$ & Rice & Deterministic & Meta-heuristics \\
\hline Lin et al. [48] & $\begin{array}{l}\text { Food and } \\
\text { ecosystem }\end{array}$ & $\mathrm{SO}$ & $\downarrow$ Environmental impacts & - & Uncertain & Goal programming \\
\hline
\end{tabular}

Note: SO: Single Objective; BO: Bi-Objective; MO: Multi-Objective; BP: Bi-level Programming; $\downarrow$ : Minimizing; $\uparrow:$ Maximizing. 
Table 1. A brief review of related researches (continued).

\begin{tabular}{|c|c|c|c|c|c|c|}
\hline \multirow{2}{*}{ Researcher } & \multirow{2}{*}{$\begin{array}{l}\text { Type of } \\
\text { problem }\end{array}$} & \multicolumn{2}{|c|}{ Objective function } & \multirow{2}{*}{$\begin{array}{l}\text { Case } \\
\text { study }\end{array}$} & \multirow{2}{*}{ Data } & \multirow{2}{*}{$\begin{array}{l}\text { Solution } \\
\text { approach }\end{array}$} \\
\hline & & Type & Description & & & \\
\hline $\begin{array}{l}\text { Cháves } \\
\text { et al. [49] }\end{array}$ & $\begin{array}{l}\text { Harvest } \\
\text { planning }\end{array}$ & MO & $\begin{array}{l}\downarrow \text { Costs, } \\
\downarrow \text { Environmental } \\
\text { impacts, } \\
\uparrow \text { Social impact }\end{array}$ & Sugarcane & Uncertain & Stochastic optimization \\
\hline Roghanian [50] & Citrus & MO & $\begin{array}{l}\downarrow \text { Costs, } \\
\downarrow \text { Environmental } \\
\text { impacts, } \\
\uparrow \text { Responsiveness }\end{array}$ & Orange & Deterministic & $\begin{array}{l}\varepsilon \text {-constraint, } \\
\text { meta-heuristics }\end{array}$ \\
\hline $\begin{array}{l}\text { Seyyed Jifroudi } \\
\text { et al. [51] }\end{array}$ & $\begin{array}{l}\text { Harvest } \\
\text { planning }\end{array}$ & MO & $\uparrow$ Total profit & Rice & Deterministic & Linear programming \\
\hline $\begin{array}{l}\text { Hosseini-Motlagh } \\
\text { et al. [52] }\end{array}$ & $\begin{array}{l}\text { Harvest } \\
\text { planning }\end{array}$ & MO & $\begin{array}{l}\downarrow \text { Total cost, } \\
\downarrow \text { non-resiliency, } \\
\downarrow \text { Impacts of social } \\
\text { responsibility }\end{array}$ & Wheat & Uncertain & $\begin{array}{l}\text { Stochastic } \\
\text { fuzzy-robust } \\
\text { programming }\end{array}$ \\
\hline $\begin{array}{l}\text { Biuki } \\
\text { et al. [53] }\end{array}$ & $\begin{array}{l}\text { Perishable } \\
\text { products }\end{array}$ & MO & $\begin{array}{l}\downarrow \text { Total cost, } \\
\downarrow \text { Environmental } \\
\text { impacts, } \\
\uparrow \text { Social } \\
\text { sustainability }\end{array}$ & - & Uncertain & Meta-heuristics \\
\hline $\begin{array}{l}\text { Jabarzadeh } \\
\text { et al. [54] }\end{array}$ & $\begin{array}{l}\text { Perishable } \\
\text { products }\end{array}$ & MO & $\begin{array}{l}\downarrow \text { Total cost, } \\
\downarrow \text { Carbon dioxide } \\
\text { emissions, } \\
\uparrow \text { Demands' } \\
\text { responsiveness }\end{array}$ & - & Deterministic & $\begin{array}{l}\text { LP-Metric and } \\
\text { weighted Tchebycheff }\end{array}$ \\
\hline $\begin{array}{l}\text { Mehrbanfar } \\
\text { et al. [55] }\end{array}$ & $\begin{array}{l}\text { Harvest } \\
\text { planning }\end{array}$ & MO & $\begin{array}{l}\uparrow \text { Employment, } \\
\downarrow \text { Greenhouse gas } \\
\text { emissions, } \\
\downarrow \text { Total costs }\end{array}$ & - & Uncertain & $\begin{array}{l}\text { Augmented } \\
\varepsilon \text {-constraint }\end{array}$ \\
\hline $\begin{array}{l}\text { Sahebjamnia } \\
\text { et al. }[56]\end{array}$ & Citrus & MO & $\downarrow$ Costs, $\uparrow$ Profits & - & Deterministic & Meta-heuristic \\
\hline Present research & $\begin{array}{l}\text { Harvest } \\
\text { planning }\end{array}$ & $\mathrm{BO}$ & $\begin{array}{l}\downarrow \text { Total costs, } \\
\downarrow \text { environmental } \\
\text { impacts }\end{array}$ & Rice & Uncertain & $\begin{array}{l}\text { Extended goal programming, } \\
\text { stochastic programming }\end{array}$ \\
\hline
\end{tabular}

Note: SO: Single Objective; BO: Bi-Objective; MO: Multi-Objective; BP: Bi-level Programming; $\downarrow$ : Minimizing; $\uparrow$ : Maximizing. 
programming is utilized to cope with uncertain data in the environmental impact function.

\section{Problem definition}

In this section, the problem and proposed mathematical model are described. The schematic of the proposed chain is shown in Figure 1. Economic issues form an integral part of a supply chain. Calculating profits or costs in a chain has always been a concern for researchers. The economics of a project in the current context of developing societies is crucial. Among the results of this work, the optimal production rate is determined. With this explanation in the present work, the main purpose of the model is to minimize the total costs of the rice supply chain. In the field of agriculture as well as industrial activities, attention should be paid to its environmental impact. Unfortunately, this issue has not received much attention in our country so far. Agricultural activities can have many destructive effects on the environment. Air pollution due to agricultural activities, soil pollution, surface and groundwater, and change in soil properties are among the destructive effects of the environment due to agricultural activities. Besides, the minimization of water used for crop cultivation and the amount of environmental damage caused by it has been considered.

The proposed rice supply chain includes farms, rice mills, distribution centers, import centers, and markets. Several factors such as transportation cost, the production cost of the rice mill, production volume, and consumer demand affect this chain. Usually, the agricultural supply chain is checked in terms of economic objective, and decision-makers in the supply chain offer the economic justification. On the other hand, other considerations such as environmental impacts, waste levels, and optimal use of biomass are raised. In the present problem, six levels have been considered for designing the rice supply chain. In countries that have climatic and weather conditions for rice production, the number of producing regions plays a significant role in rice production. All processing centers are placed in the producer area and satisfied rice mills orders. Rice mills transfer final products to distribution centers and after packing them, these packages can be distributed to the retailers in markets. Moreover, import centers are supported by other countries that play an important role in providing a significant part of the community demand. These centers can be prioritized in terms of quality and type of rice as well as the analysis of import costs. Imported rice is first transferred to some distribution centers and then, sent to the final market. Unhusked rice is a product that has been taken from farms and then, rice mills changed it to white rice as the main product of the chain. The market as the final part of the chain is a retailer and its demand is proportional to the population of each market region. The demand for markets is provided directly from rice mills and through distribution centers.

\subsection{Mathematical model}

As discussed in the previous section, the proposed mathematical model is composed of two linear objective functions and attempt to minimize costs and environmental impacts. The following is a description of its components:

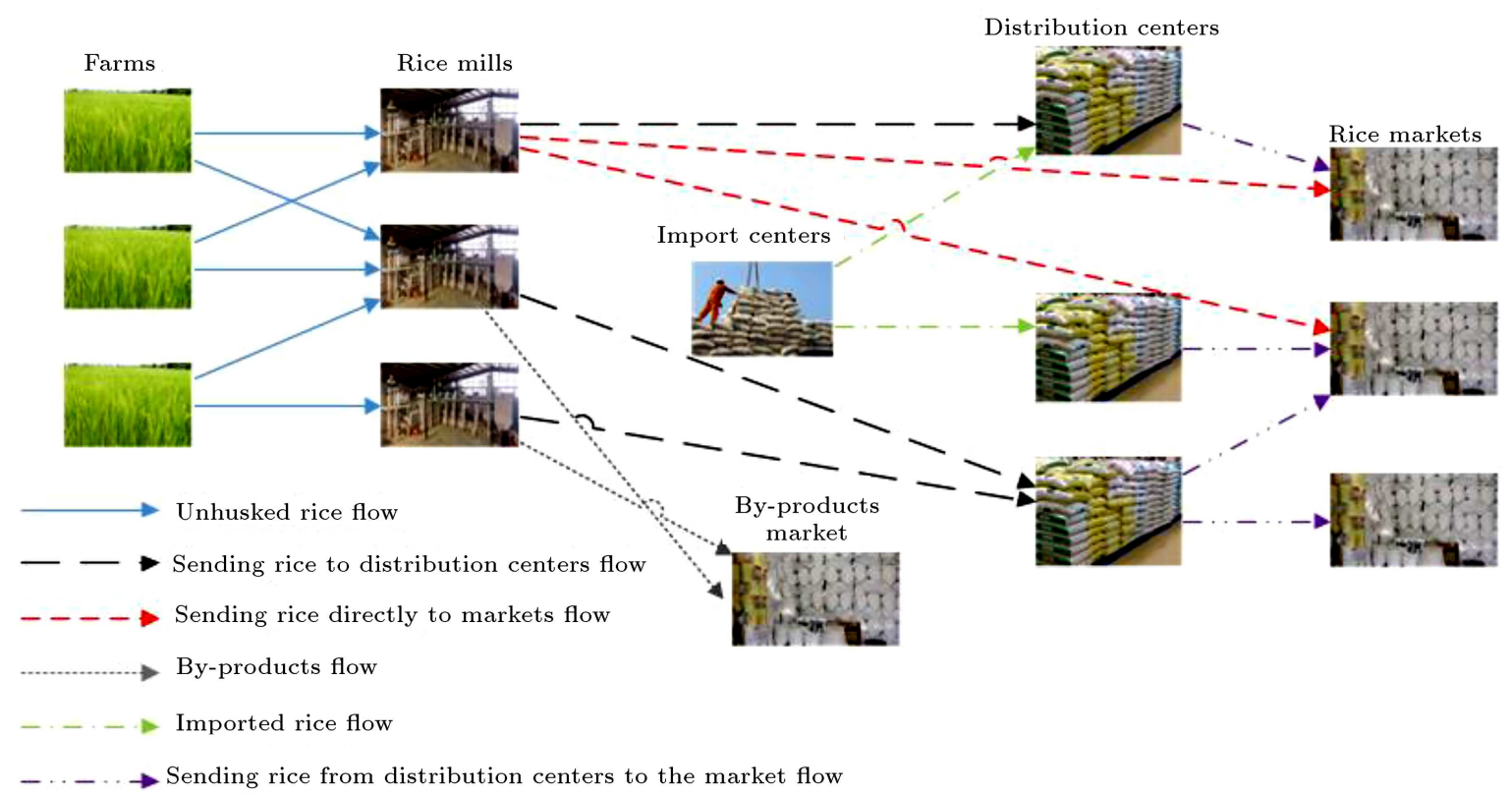

Figure 1. The schematic of the proposed model. 
Indices:

$i \quad$ Index of farm $i=(1, \cdots, I)$

$j \quad$ Index of rice mill $j=(1, \cdots, J)$

$k \quad$ Index of distribution centers $k=(1, \cdots, K)$

$s \quad$ Index of rice import centers $s=(1, \cdots, S)$

$n \quad$ Index of rice market $n=(1, \cdots, N)$

$q \quad$ Index of by-product $q=(1, \cdots, Q)$

Parameters:

$c_{i j}^{1} \quad$ The transportation cost of unhusked rice from farm $i$ to rice mill $j$

$c_{j k}^{2} \quad$ The transportation cost of rice from rice mill $j$ to distribution center $k$

$c_{j n}^{3} \quad$ The transportation cost of rice from rice mill $j$ to market $n$

$c_{j q}^{4} \quad$ The transportation cost of by-product $q$ from rice mill $j$ to the market

$c_{s k}^{5} \quad$ The transportation cost of rice from import center $s$ to distribution center $k$

$c_{k n}^{6} \quad$ The transportation cost of rice from distribution center $k$ to market $n$

$p_{j} \quad$ The processing cost in rice mill $j$

$\lambda_{i} \quad$ The producing cost of rice on the farm $i$

$\mu \quad$ Maximum allowed demand ratio to import

$\omega_{s} \quad$ The import cost of rice from import center $s$

$v_{k} \quad$ The capacity of distribution center $k$

$d_{j} \quad$ The processing capacity of rice mill $j$

$\beta \quad$ Rice processing coefficient

$\alpha_{q} \quad$ The coefficient of processing byproduct $q$ obtained from the unhusked rice

$d_{e} m_{n} \quad$ The rice demand in market $n$

$\operatorname{dem}_{q}^{\prime} \quad$ The market demand for by-product $q$

$\gamma_{n} \quad$ Direct purchases coefficient of rice in the market $n$

$c f e_{i} \quad$ Amount of damage to the environment on the farm $i$

$s u_{i} \quad$ The maximum level of cultivating rice on the farm $i$ in a hectare

$\theta_{i} \quad$ Production ratio of unhusked rice per hectare in farm $i$

$C w b_{i} \quad$ The available water coefficient of irrigation in farm $i\left(\mathrm{~m}^{3}\right.$ per hectare $)$

$C w g_{i}$ The available water coefficient of rainfall in farm $i\left(\mathrm{~m}^{3}\right.$ per hectare)
Decision variables:

Sur $_{i} \quad$ Under cultivation area of farm $i$ (hectare)

$X_{i j} \quad$ Quantity of transferred unhusked rice from farm $i$ to rice mill $j$

$Y_{j k} \quad$ Quantity of transferred rice from rice mill $j$ to distribution center $k$

$Z_{s k} \quad$ Quantity of import rice from import center $s$ to distribution center $k$

$W_{k n} \quad$ Quantity of transferred rice from distribution center $k$ to market $n$

$Y_{j n}^{\prime} \quad$ Quantity of transferred rice from rice mill $j$ to market $n$

$Y_{j q}^{\prime \prime} \quad$ Quantity of transferred by-product $q$ from rice mill $j$ to the consumer market

$C w r_{i c} \quad$ Quantity of total used water in farm $i$

$W g_{i} \quad$ Quantity of provided water by rainfall in farm $i\left(\mathrm{~m}^{3}\right)$

$W b_{i} \quad$ Quantity of provided water by irrigation in farm $i\left(\mathrm{~m}^{3}\right)$

Objective functions:

$\min$ costs $=$

$$
\begin{aligned}
& \sum_{i} \sum_{j} X_{i j} \times c_{i j}^{1} \\
& +\sum_{j} \sum_{k} Y_{j k} \times c_{j k}^{2} \\
& +\sum_{j} \sum_{n} Y_{j n}^{\prime} \times c_{j n}^{3} \\
& +\sum_{j} \sum_{q} Y_{j q}^{\prime \prime} \times c_{j q}^{4}, \\
& +\sum_{k} \sum_{n} W_{k n} \times c_{s k}^{5}, \\
& +\sum_{s} \sum_{k} z_{s k} \times c_{k n}^{6}, \\
& +\sum_{i} \sum_{j} X_{i j} \times \lambda_{i}, \\
& +\sum_{i} \sum_{j} X_{i j} \times p_{j}, \\
& +\sum_{s} \sum_{k} z_{s k} \times \omega_{s}
\end{aligned}
$$

min environmental impacts $=\sum_{i}\left[c f e_{i} \times C w r_{i}\right]$.

Eq. (1-1) represents the cost of transferring the unhusked rice from farms to rice mills. Eq. (1-2) indicates 
the transportation cost of rice from rice mills to distribution centers. Eq. (1-3) indicates the cost of transporting rice after packaging in distribution centers to the markets. Eq. (1-4) shows the cost of transporting by-products from rice mills to the relevant market. Eq. (1-5) shows the transportation cost of rice from the import centers to the distribution centers. Eq. (1-6) shows the transportation cost of rice from distribution centers to markets. Eq. (1-7) represents the production cost in farms (including manure, poison, equipment purchase, and manpower costs). Eq. (1-8) represents the rice mill costs for converting and processing rice. Eq. (1-9) shows the cost of importing rice (including rice purchases, shipping costs, and customs fees) from import centers.

The second objective function addresses the environmental impacts of used water on rice cultivation in farms. The environmental damage factor can be stated as the rate of destruction of agricultural farms due to water consumption. Part of the surface water entering the earth, due to the environmental damage factor, causes erosion of farms within a year. This coefficient is directly related to the climate and the type of soil cover in each area. $c f e_{i}$ indicates that every $\mathrm{m}^{3}$ of used water eliminates several $\mathrm{m}^{3}$ of agricultural firms over a period of one year.

Eq. (2) indicates the soil damage due to water consumption. Water in each area exists on the surface and in irrigation. Surface water is caused by the rainfall while irrigation water is originated from aquifers and underground. These are used for one-year rice cultivation, and the use of these types of water leads to the erosion and destruction of the surface layer and part of the soil. The coefficient of soil loss in the farms depends on the genus and type of coverage.

\section{Constraints:}

$$
\begin{array}{ll}
\beta \sum_{i} X_{i j}=\sum_{k} Y_{j k}+\sum_{n} Y_{j n}^{\prime} & \forall j, \\
\sum_{j} Y_{j k}+\sum_{s} Z_{s k}=\sum_{n} W_{k n} & \forall k, \\
\sum_{q} \alpha_{q}+\beta=1, & \forall j, q, \\
\sum_{i} X_{i j} \cdot \alpha_{q}=Y_{j q}^{\prime \prime} & \\
\sum_{j} Y_{j q}^{\prime \prime} \geq d e m_{q}^{\prime} & \forall q, \\
\sum_{k} W_{k n}+\sum_{j} Y_{j n}^{\prime} \geq \text { dem }_{n} & \forall n,
\end{array}
$$

$$
\begin{array}{ll}
\sum_{j} X_{i j} \leq \theta_{i} \times S u r_{i} & \forall i, \\
\sum_{i} X_{i j} \leq d_{j} & \forall j, \\
\sum_{j} Y_{j k}+\sum_{s} Z_{s k} \leq v_{k} & \forall k, \\
\sum_{j} Y_{j n}^{\prime} \geq d e m_{n} \times \gamma_{n} & \forall n, \\
\sum_{s} \sum_{k} Z_{s k} \leq \mu \cdot \sum_{n} d e m_{n}, & \\
S u r_{i} \leq s u_{i} & \forall i, \\
C w r_{i}=W g_{i}+W b_{i} & \forall i, \\
W g_{i}=C w g_{i} \times S u r_{i} & \forall i, \\
W b_{i}=C w b_{i} \times S u r_{i} & \\
S u r_{i}, X_{i j}, Y_{j k}, Z_{s k}, W_{k n}, Y_{j n}^{\prime}, Y_{j q}^{\prime \prime}, C w r_{i}, \\
W g_{i}, W b_{i} \geq 0 & \forall i, \\
& \forall, n, q .
\end{array}
$$

According to Eq. (3), the quantity of obtained rice from the rice mill should be equal to the quantity of rice that is sent directly to markets and distribution centers, meaning that there is no waste along the supply chain. Eq. (4) is balance equality, which states that the quantity of rice shipped from the distribution center to the market should be equal to the quantity of produced rice and imported rice. Eq. (5) shows a balance relation for the conversion coefficients of all products obtained from the unhusked rice, and their summation is equal to one. It represents that there is no distraction in the rice mill. The following constraints are related to the production of by-products, including crushed rice and rice bran that are produced at the rice mill with their conversion coefficients. Eq. (6) refers to the byproduct from a rice mill that is sent directly to the byproducts markets. Constraint (7) guarantees that the by-product produced in rice mills should be more than the by-product market demand. Constraint (8) reflects the balance between rice demand and supply. Constraint (9) shows the maximum permitted cultivable amount in farms. Constraint (10) represents that the quantity of transferred unhusked rice from farms to rice mills is less than, or equal to, the rice mill's capacity. Constraint (11) reflects the limited capacity of distribution centers. Constraint (12) implies the demand transmitted directly from the rice mill to the market. This coefficient can be different in each production region. Eq. (13) indicates that import 
centers are allowed to supply the maximum part of total demand.

Eq. (14) shows that in each production area (farms), rice production requires a limited space with suitable conditions for cultivation. It is always less than the amount of free and available space.

Constraints (15) to (17) are related to environmental impacts. The total amount of water used for rice cultivation comes from two sources: the amount of ground water and water generated by precipitation. $W g_{i}$ represents the amount of precipitation water consumed during an agricultural period in the farms that can be used as surface water, and $W b_{i}$ indicates the amount of irrigation water in farms that can be considered as a significant part of the water consumption. It includes surface water and irrigation water as illustrated in Eq. (15). Eq. (16) shows the amount of water generated by precipitation which is controlled in each region based on a correlated factor with the area under cultivation. Eq. (17) controls the amount of needed groundwater for cultivation according to the specific coefficient, which is related to the available level for cultivation.

\section{Solution approach}

In this section, the applied solution approach to solving the proposed model is described. To deal with uncertainty, stochastic programming is used under different scenarios. Correspondingly, to solve the proposed bi-objective mathematical model, an extended goal programming method is applied.

\subsection{Stochastic programming}

In most real optimization problems, estimated parameters are not accurate and dependent on different conditions. Meanwhile, the collection of accurate information depends on human judgment and this issue is very difficult or is not practical [31]. Stochastic programming is one of the most considered approaches that provides a framework for modeling optimization problem, which is not deterministic. Generally, deterministic optimization problems are formulated with deterministic and definite parameters, but real-world problems usually include some unknown and uncertain information. The purpose of stochastic programming is to take an optimal decision on problems with uncertain and random parameters [32].

A sample space, e.g., $\Omega$, is described for uncertain parameters. It is composed of scenarios. Each scenario may occur with an estimated probability. Thus, $\Omega$ is defined as a set of specific scenarios in the model below:

$$
\left\{\omega_{1}, \omega_{2}, \cdots, \omega_{s}\right\}
$$

The probabilities associated with this set will be listed as the following constraints:

$$
\begin{aligned}
& p\left(\omega_{k}\right) \geq 0, \\
& \sum_{k=1}^{s} p\left(\omega_{k}\right)=1 .
\end{aligned}
$$

\subsubsection{Equivalent certain model}

Water consumed for rice cultivation is provided from two sources: surface water and irrigation water. Annual rainfall and groundwater levels are difficult to predict. In this situation, the uncertainty in the model causes instability in the data for analysis. To cope with uncertainty, a stochastic programming method is employed. A definitive equivalent model is given in this subsection.

Index:

$c \quad$ Index of scenario $c=(1,2,3)$

Parameters:

$C w b_{i c} \quad$ The available water coefficient of irrigation in farm $i$ under scenario $c$ $\left(\mathrm{m}^{3}\right.$ per hectare)

$C w g_{i c}$ The available water coefficient of rainfall in farm $i$ under scenario $c\left(\mathrm{~m}^{3}\right.$ per hectare)

$p_{c} \quad$ The probability of occurrence of scenario $c$

Decision variables:

$C w r_{i c} \quad$ Quantity of total used water in farm $i$ under scenario $c$

$W g_{i c} \quad$ Quantity of provided water by rainfall in farm $i$ under scenario $c$

$W b_{i c} \quad$ Quantity of provided water by irrigation in farm $i$ under scenario $c$

Objective functions:

The first objective function does not change; however, the second is updated as follows:

$$
\begin{gathered}
\text { min environment impacts }=\sum_{c} \sum_{i} p_{c} \\
\times\left[c f e_{i} \times C w r_{i c}\right] .
\end{gathered}
$$

Constraints:

Subject to Constraints (3) to (14) and:

$$
\begin{array}{cc}
C w r_{i c}=W g_{i c}+W b_{i c} & \forall i, c, \\
W g_{i c}=C w g_{i c} \times S u r_{i} & \forall i, c, \\
W b_{i c}=C w b_{i c} \times S u r_{i} \quad & \forall i, c, \\
S u r_{i}, X_{i j}, Y_{j k}, Z_{s k}, W_{k n}, Y_{j n}^{\prime}, Y_{j q}^{\prime \prime}, C w r_{i c}, \\
W g_{i c}, W b_{i c} \geq 0 \quad \forall i, j, s, k, n, q, c .
\end{array}
$$

4.2. The extended goal programming method Here, an extended goal programming method is utilized 
to transform the proposed bi-objective model into a single-objective model. This method was introduced by Romero in 2003 [33] as an attempt to balance the different goal levels in each objective function considering a parametric survey. The general form of the proposed model is as follows:

$$
\begin{array}{cc}
\min & \alpha=\alpha \lambda+(1-\alpha)\left\{\sum_{i=1}^{q}\left(\frac{u_{i} n_{i}}{b_{i}}+\frac{v_{i} p_{i}}{b_{i}}\right)\right\}, \\
\text { s.t. } & \frac{u_{i} n_{i}}{b_{i}}+\frac{v_{i} p_{i}}{b_{i}} \leq \lambda \quad i=1, \cdots, q, \\
& f_{i}(x)+n_{i}-p_{i}=b_{i} \quad i=1, \cdots, q, \\
& \underline{x} \in F, n_{i}, p_{i} \geq 0 \quad i=1, \cdots, q,
\end{array}
$$

where the above model has $q$ objectives and $x$ decision variables and $b_{i}$ is the expected value of the objective function. The decision variables $n_{i}$ and $p_{i}$ determine the positive and negative values of the $i$ th objective function, respectively. The maximum weighted deviation from the unwanted deviations is shown by $\lambda$. Correspondingly, two weight parameters $u_{i}$ and $v_{i}$ are related to different levels of the objective function and seek to minimize the positive and negative deviations from the $i$ th objective function. Furthermore, $\alpha$ is a parameter that controls the relative importance of performance and competence in the model.

The extended goal programming model provides the best combination of optimization, balancing, and satisfaction with the diversion of the main objectives as well as the single decision-making [34]. The satisfaction of optimization is achieved by minimizing the total weight of the deviations. The balance of the model is obtained by guaranteeing the maximum deviation in the first part of Eq. (26). Moreover, the balance between optimization and achievement can be controlled at each level through the parameter $\alpha$, which can fully emphasize optimization by setting $(\alpha=0)$ and focus on achieving goals by setting $(\alpha=1)$.

\subsubsection{Proposed goal programming model}

According to the explanation, the extended goal programming model is formulated as follows:

$$
\begin{gathered}
\min \alpha=\alpha \lambda+(1-\alpha)\left\{\left(\frac{u_{1} n_{1}}{b_{1}}+\frac{v_{1} p_{1}}{b_{1}}\right)\right. \\
\left.+\left(\frac{u_{2} n_{2}}{b_{2}}+\frac{v_{2} p_{2}}{b_{2}}\right)\right\}, \\
\frac{u_{1} n_{1}}{b_{1}}+\frac{v_{2} p_{2}}{b_{2}} \leq \lambda, \\
\frac{u_{1} n_{1}}{b_{1}}+\frac{v_{2} p_{2}}{b_{2}} \leq \lambda,
\end{gathered}
$$

$$
\begin{aligned}
& f_{1}(x)+n_{1}-p_{1}=b_{1}, \\
& f_{2}(x)+n_{2}-p_{2}=b_{2}, \\
& n_{1}, p_{1}, n_{2}, p_{2} \geq 0 .
\end{aligned}
$$

Subject to Constraints (3) to (14) and (22) to (25).

\section{Case study}

In this section, a real case study is carried out to validate the proposed model in the rice supply chain. First, the model parameters related to the case study are reported. Then, the model findings and recommendations are given and finally, the sensitivity analyses are performed on the key parameters and the results are expressed.

\subsection{Assumptions}

The following assumptions are considered in modeling the case study:

- The number of farms and rice mills is equivalent. In each producer area (farm), there is a rice mill. Shifting between these rice mills is allowed;

- The distance between each plant and farm is fixed. Because in each rice producer area, a farm and a rice mill are considered; thus, the distance between them is assumed constant;

- The transportation vehicles for rice and unhusked rice are the same, and the cost of carrying rice and unhusked rice is known;

- The processing costs of rice mills to produce white rice and by-products are the same, because all of them are processed in one place and all are unhusked rice products;

- The performance of rice mills in terms of the coefficient of converting unhusked rice into rice and the production of by-products is fixed for all regions;

- The amount of import is limited and it responds to a ratio of the demand;

- Four options for importing rice are given and only two distribution centers are considered;

- Water consumption for rice cultivation is calculated in $\mathrm{m}^{3}$ per ton for each hectare;

- Surface water is the metric used to calculate the damage to the environment.

\subsection{Case description}

In this research, a bi-objective model for the rice supply chain with economic and environmental purposes is designed to meet the needs of the Iranian people. In this country, 17 provinces out of 31 produce rice, and about 2.5 million tons of white rice is produced annually. However, four important farms with the 
highest share in supplying rice have been considered: Mazandaran, Gilan, Khuzestan, and Golestan. Here, four farms, four rice mills, six distribution centers, four import centers, two by-products, and 32 market areas are considered in this case study. In this research, water supply for rice cultivation is carried out in two ways: rainwater and irrigation water. Three scenarios for water supply are considered as follows:

- Good scenario: The best weather conditions in terms of rainfall and less use of irrigation water resources;

- Medium scenario: Good weather conditions in terms of rainfall and balanced use of irrigation water resources;

- Bad scenario: Inappropriate weather conditions in terms of rainfall and excessive use of irrigation water resources.

After the harvesting stage of the unhusked rice from farms, it is transferred to rice mills in the same production area. In the processing stage of unhusked rice, the rice mill turns into the rice and two by-products (rice bran and broken rice). A given portion of white rice will be sent to the distribution center for packaging and distribution in the market. In this case, six distribution centers are considered. In Mazandaran, Gilan, and Tehran, three, one, and two distribution centers are located, respectively. In the designed model, rice markets are retailers in all regions of the country (equivalent to the number of provinces). The retailer of each province receives rice from two sources. It can be transferred directly from rice mills and distribution centers, as well.

\subsection{Parameters setting}

This section studies the data collected on the various components of the rice supply chain. This chain includes four production regions with a limited rice cultivation capacity. The farm data, in each region, are given in Table 2. The climatic type of each region determines the rate of water requested for irrigation of each agricultural farms. Water provided from irrigation is the sum of underground and surface water from rainfall and snowfall. In Table 3, the environmental parameters related to the second objective function are given. In each production area, a plant is considered with a specific processing capacity and production cost according to the production capacity of the rice production. Table 4 represents the processing capacity and cost of rice mills. Moreover, distribution centers have a limited capacity, as given in Table 5. The costs

Table 2. Farms availability in each region.

\begin{tabular}{|c|c|c|c|c|}
\hline & \multicolumn{4}{|c|}{ Farm } \\
\hline & Mazandaran & Gilan & Khuzestan & Golestan \\
\hline Maximum level of cultivation (hectare) & 291,666 & 234,000 & 100,000 & 163,000 \\
\hline Unhusked rice production factor (ton per hectare) & 4.8 & 5 & 4 & 4.3 \\
\hline Production cost for unhusked rice $(1,000$ tomans per ton $)$ & 110 & 100 & 120 & 115 \\
\hline
\end{tabular}

Table 3. Environmental impacts and its parameters.

\begin{tabular}{|c|c|c|c|c|c|}
\hline & \multirow{2}{*}{ Scenario } & \multicolumn{4}{|c|}{ Farm } \\
\hline & & Mazandaran & Gilan & Khuzestan & Golestan \\
\hline \multirow{3}{*}{ Coefficients of irrigation water } & 1 & 0.48 & 0.32 & 0.52 & 0.39 \\
\hline & 2 & 0.52 & 0.38 & 0.7 & 0.5 \\
\hline & 3 & 0.59 & 0.45 & 0.79 & 0.6 \\
\hline \multirow{3}{*}{ Coefficients of water from rainfall } & 1 & 0.4 & 0.54 & 0.22 & 0.31 \\
\hline & 2 & 0.48 & 0.62 & 0.3 & 0.4 \\
\hline & 3 & 0.56 & 0.7 & 0.4 & 0.47 \\
\hline Environmental damage factor & & 0.006 & 0.006 & 0.05 & 0.01 \\
\hline
\end{tabular}

Table 4. Rice mills information.

\begin{tabular}{lcccc}
\hline & \multicolumn{3}{c}{ Rice mill } \\
\cline { 2 - 5 } & Mazandaran & Gilan & Khuzestan & Golestan \\
\hline The processing cost of unhusked rice (1,000 tomans per ton) & 300 & 305 & 315 & 310 \\
Processing capacity of rice mill (1,000 tons) & 1,500 & 1,400 & 700 & 950 \\
\hline
\end{tabular}


of imported rice from each import center are composed of shipping costs from rice mills, customs fees, and rice-buying costs. Table 6 gives the imported rice information.

According to the Rice Research Center, per capita, rice consumption is $36 \mathrm{~kg}$ per person. The annual demand for each region has been calculated based on the population residing in this region in the latest official census. For example, the population of Mazandaran province in 2018 was 3,280,000; thus, yearly rice demand in Mazandaran can be quantified as $3,280,000 \times 36=118,080,000 \mathrm{~kg}$. Table 7 shows the rice demand which is directly generated from each market. For example, this coefficient in Mazandaran, Qazvin, and South Khorasan provinces is 0.6, 0.45, and 0.2 , respectively. This value for the main producer regions is higher, and the lower amount is assigned to non-producers.
In the proposed model, transportation costs for transferring rice to different chain levels are considered. To calculate transportation costs, the Google Map Guide is employed to determine the proper route with the closest distance between the provinces. Only one type of vehicle is used to transfer rice within the chain and the transportation cost is estimated at 1,000 Tomans per ton per kilometer.

As mentioned above, in addition to the main product (white rice), two by-products (rice bran and broken rice) are also produced at rice mills, which are directly transported to their respective market. Table 8 gives the required data related to by-products.

\subsection{Results and discussion}

The proposed bi-objective model has been coded in LINGO 09 software. The goal programming approach is applied to handle the bi-objective model. In this

Table 5. The capacity of distribution centers.

\begin{tabular}{ccccccc}
\hline & \multicolumn{7}{c}{ Distribution center } \\
\cline { 2 - 8 } & $\mathbf{1}$ & $\mathbf{2}$ & $\mathbf{3}$ & $\mathbf{4}$ & $\mathbf{5}$ & $\mathbf{6}$ \\
\hline Capacity (ton) & 320,000 & 300,000 & 200,000 & 350,000 & 200,000 & 190,000 \\
\hline
\end{tabular}

Table 6. Import center information.

\begin{tabular}{lcccc}
\hline & \multicolumn{4}{c}{ Import center } \\
\cline { 2 - 5 } & $\mathbf{1}$ & $\mathbf{2}$ & $\mathbf{3}$ & $\mathbf{4}$ \\
\hline Import centers' capacity (ton) & 600,000 & 250,000 & 100,000 & 100,000 \\
The cost of importing rice (toman per ton) & 2,200 & 2,280 & 1,440 & 1,080 \\
\hline
\end{tabular}

Table 7. Direct purchasing ratio and market demand.

\begin{tabular}{|c|c|c|c|c|c|}
\hline Market & $\begin{array}{l}\text { Direct purchase } \\
\text { coefficient }\end{array}$ & $\begin{array}{l}\text { Demand } \\
\text { (ton) }\end{array}$ & Market & $\begin{array}{l}\text { Direct purchase } \\
\text { coefficient }\end{array}$ & $\begin{array}{l}\text { Demand } \\
\text { (ton) }\end{array}$ \\
\hline Mazandaran & 0.6 & 118,080 & Tehran & 0.25 & 477,612 \\
\hline Gilan & 0.6 & 90,000 & Alborz & 0.18 & 97,632 \\
\hline Ardabil & 0.2 & 45,720 & Qazvin & 0.42 & 45,828 \\
\hline East Azerbaijan & 0.4 & 140,724 & Zanjan & 0.38 & 38,052 \\
\hline West Azerbaijan & 0.18 & 117,540 & Hamadan & 0.2 & 62,568 \\
\hline Kurdistan & 0.2 & 57,708 & Lorestan & 0.42 & 63,360 \\
\hline Kermanshah & 0.4 & 70,272 & Chaharmahal and Bakhtiari & 0.42 & 34,092 \\
\hline Ilam & 0.41 & 20,880 & Kohgiluyeh and Boyer-Ahmad & 0.38 & 25,668 \\
\hline Khuzestan & 0.6 & 169,560 & Fars & 0.45 & 174,636 \\
\hline Bushehr & 0.2 & 41,868 & Kerman & 0.2 & 113,904 \\
\hline Hormozgan & 0.2 & 63,936 & Yazd & 0.2 & 40,968 \\
\hline Sistan and Baluchestan & 0.35 & 99,900 & Isfahan & 0.41 & 184,320 \\
\hline South Khorasan & 0.2 & 27,648 & Markazi & 0.18 & 51,444 \\
\hline Razavi Khorasan & 0.2 & 231,624 & Qom & 0.2 & 46,512 \\
\hline North Khorasan & 0.38 & 31,068 & Semnan & 0.18 & 25,272 \\
\hline Golestan & 0.6 & 67,248 & & & \\
\hline
\end{tabular}


Table 8. By-products Information.

\begin{tabular}{llcc}
\hline & \multirow{2}{*}{ Rice mill } & \multicolumn{2}{c}{ By-product } \\
\cline { 3 - 4 } & & Rice bran & Broken rice \\
\hline & Gizandaran & 20 & 20 \\
Transportation cost (1,000 tomans per ton) & Khuzestan & 20 & 20 \\
& Golestan & 20 & 20 \\
Demand (ton) & & 250,000 & 100,000 \\
Production factor (per ton) & & 0.3 & 0.1 \\
\hline
\end{tabular}

Table 9. Calculated objective function values.

\begin{tabular}{lccc}
\hline & $\begin{array}{c}\text { Objective } \\
\text { function } \boldsymbol{Z}_{\mathbf{1}}\end{array}$ & $\begin{array}{c}\text { Objective } \\
\text { function } \boldsymbol{Z}_{\mathbf{2}}\end{array}$ & $\begin{array}{c}\text { Goal programming } \\
\text { method }\end{array}$ \\
\hline Objective function values $\boldsymbol{Z}_{\mathbf{1}}$ & $4,579,278,000$ & $15,423,440,000$ & $5,290,869,000$ \\
Objective function values $\boldsymbol{Z}_{\mathbf{2}}$ & 9.6 & 4 & 4.62 \\
Production percentage & $76 \%$ & $63 \%$ & $68.2 \%$ \\
Import percentage & $24 \%$ & $37 \%$ & $31.8 \%$ \\
Deviation from $\boldsymbol{Z}_{\mathbf{1}}$ & 0 & $236 \%$ & $15 \%$ \\
Deviation from $\boldsymbol{Z}_{\mathbf{2}}$ & $139 \%$ & 0 & $15 \%$ \\
\hline
\end{tabular}

model, the parameters $u$ and $v$ are determined to control the deviations of the objective functions and then, the model is performed. The value of $u$ and $v$ for the economic objective function is set to 0.35 .

In Table 9, objective function values are given in three different modes as well as the number of deviations from the goal answer. In the first case, each of the objective functions is executed separately, in which the answer is considered as the goal value $\left(b_{i}\right)$. Moreover, production and import ratios are given for each objective function.

According to Figure 2, the model recommends that the amount of produced unhusked rice be equal to the maximum production capacity of rice on all farms except Khuzestan. Due to the lack of water as well as the effect of the environmental objective on rice cultivation, production in Khuzestan province is not justified. The model recommends more import quantities to supply. Interestingly, based on the coun-

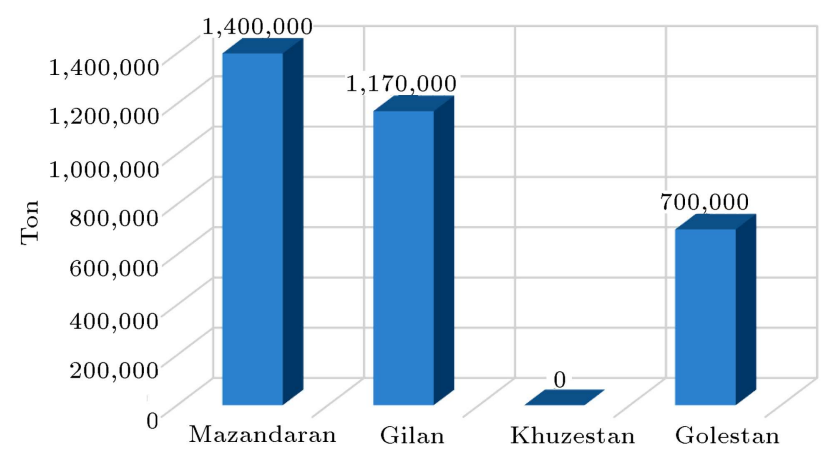

Figure 2. Amount of produced unhusked rice. try's water-saving policies, rice cultivation is prohibited in Khuzestan province in the current and coming agricultural years. Similarly, unhusked rice, rice, and by-products are not produced in this province.

Figure 3 shows the amount of rice sent to distribution centers from rice mills. It is noticeable that the fourth and sixth distribution centers received zero rice from rice mills. Besides, Table 10 indicates the amount of rice received at distribution centers from import centers.

Figure 4 shows the production rate of by-products in each rice mill. Information about the second objective function, including the amount of water used, is given in Table 11. To better understand the environmental impacts, Figure 5 shows the impact of different types of water on agricultural land under different scenarios. As shown in the previous tables, the amount of production in Khuzestan province is zero;

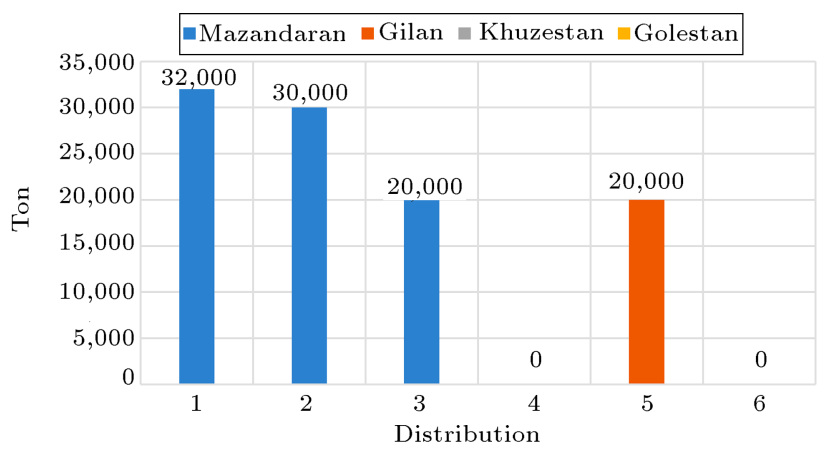

Figure 3. The amount of rice sent from rice mills to distribution centers. 
Table 10. The amount of rice sent from imported centers to distribution centers (Ton).

\begin{tabular}{ccccccc}
\hline \multirow{2}{*}{ Import center } & \multicolumn{7}{c}{ Distribution center } \\
\cline { 2 - 7 } & $\mathbf{1}$ & $\mathbf{2}$ & $\mathbf{3}$ & $\mathbf{4}$ & $\mathbf{5}$ & $\mathbf{6}$ \\
\hline 1 & 0 & 0 & 0 & 350,000 & 60,000 & 190,000 \\
2 & 17,334 & 76,309 & 0 & 0 & 20,000 & 0 \\
3 & 0 & 0 & 0 & 0 & 100,000 & 0 \\
4 & 100,000 & 0 & 0 & 0 & 0 & 0 \\
\hline
\end{tabular}

Table 11. Effects of the environment on the fields $\left(\mathrm{m}^{2} / \mathrm{m}^{3}\right.$ year $)$.

\begin{tabular}{lccccc}
\hline \multirow{2}{*}{ Variables } & \multirow{2}{*}{ Scenario } & \multicolumn{5}{c}{ Farm } \\
\cline { 3 - 6 } & & Mazandaran & Gilan & Khuzestan & Golestan \\
\hline \multirow{2}{*}{ Coefficients of irrigation water } & 1 & 116.66 & 72.54 & 0 & 113.95 \\
& 2 & 157.5 & 112.32 & 0 & 65.116 \\
& 3 & 64.166 & 145.08 & 0 & 76.511 \\
Coefficients of water from rainfall & 1 & & & & \\
& 2 & 93.33 & 121.68 & 0 & 128.604 \\
& 3 & 151.66 & 88.92 & 0 & 97.674 \\
Environmental damage factor & 1 & 256.666 & 163.8 & 0 & 187.209 \\
& 2 & 250.833 & 234 & 0 & 193.72 \\
& 3 & 215.833 & 234 & 0 & 174.186 \\
\hline
\end{tabular}

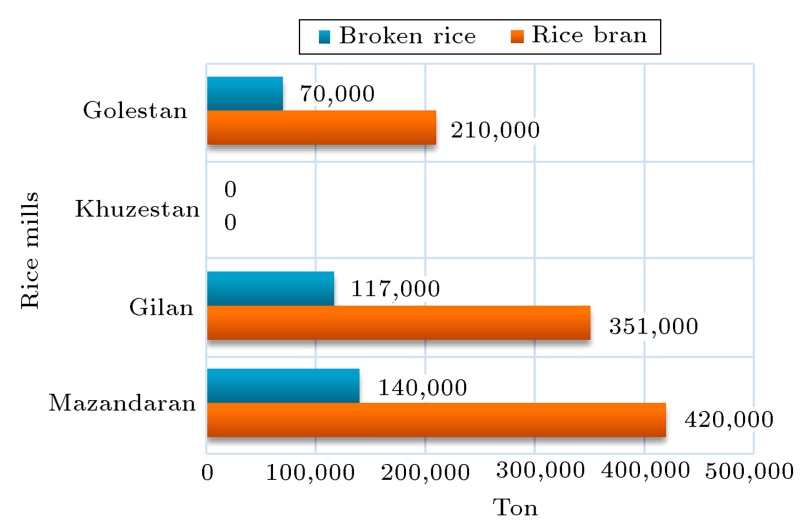

Figure 4. By-products produced in rice mills.

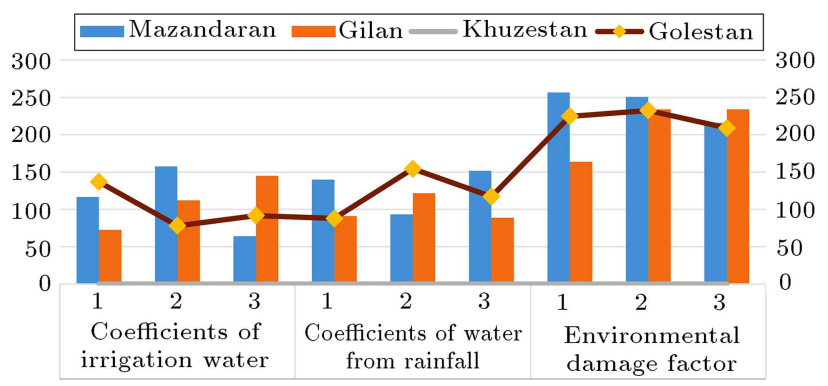

Figure 5. Effects of environmental impact on agricultural fields in different scenarios.

therefore, the amount of environmental effects has not been considered.

\subsection{Sensitivity analyses}

In this section, three sensitivity analyses on the model parameters are discussed. First, the magnitude of the input data from the required water coefficient including water from irrigation and rainfall on the model decisions is discussed. Three scenarios are considered in the original model for one farming year and the climate condition. Drought and water-rich years for agriculture are two natural states with certain different coefficients. Table 3 shows the different coefficients of agricultural irrigation sources conditions. As indicated by the coefficients, there is a need for allocating a certain amount of water to rice cultivation, and these needs are satisfied in two ways. If rainfall is low, the use of groundwater is increased, and vice versa. Table 12 shows the model solutions for different scenarios. As is given in Table 12, the deviation of the objective function in the bad scenario is a negative number, which indicates a decrease in environmental damage due to less rainfall and more resource use. Better annual precipitation leads to better rice production. Upon enhancing precipitation scenarios, rice production also increases. In the third scenario (good), one can see that $73 \%$ of rice demand is produced in the country farms and the import level is reduced. Moreover, production in Khuzestan province is planned only in good weather conditions. This issue is shown in Table 12. To understand this issue better, Figure 6 shows the production done in provinces in different scenarios with the stochastic method and as it is known, Mazandaran and Gilan provinces have the highest rice production with $1,400,000$ and 1,170,000 tons, respectively. Figure 7 shows the ratio of rice production and import in different scenarios and stochastic programming approach. In stochastic programming, the amount of production 
Table 12. Sensitivity analysis of each scenario.

\begin{tabular}{|c|c|c|c|c|c|c|c|c|c|c|}
\hline & \multirow{2}{*}{$\begin{array}{l}\text { Production } \\
\text { ratio }\end{array}$} & \multirow[t]{2}{*}{$\begin{array}{l}\text { Import } \\
\text { ratio }\end{array}$} & \multirow[t]{2}{*}{$Z_{1}$} & \multirow[t]{2}{*}{$Z_{2}$} & \multicolumn{2}{|c|}{$\begin{array}{c}\text { Deviation } \\
\text { from } \\
\end{array}$} & \multicolumn{4}{|c|}{$\begin{array}{l}\text { The amount of unhusked } \\
\text { rice production }\end{array}$} \\
\hline & & & & & $b_{1}$ & $b_{2}$ & Mazandaran & Gilan & Khuzestan & Golestan \\
\hline First scenario (bad) & $63 \%$ & $37 \%$ & $5,582,437,000$ & 3.8 & $30 \%$ & $-5 \%$ & $1,400,000$ & $1,170,000$ & 0 & 449,446 \\
\hline Second scenario (medium) & $69 \%$ & $31 \%$ & $5,290,869,000$ & 4.62 & $15 \%$ & $15 \%$ & $1,400,000$ & $1,170,000$ & 36,991 & 700,000 \\
\hline Third scenario (good) & $73 \%$ & $27 \%$ & $5,274,191,000$ & 5.37 & $15 \%$ & $38 \%$ & $1,400,000$ & $1,170,000$ & 228,700 & 700,000 \\
\hline Stochastic method & $68 \%$ & $32 \%$ & $5,290,869,000$ & 4.61 & $15 \%$ & $15 \%$ & $1,400,000$ & $1,170,000$ & 0 & 689,063 \\
\hline
\end{tabular}

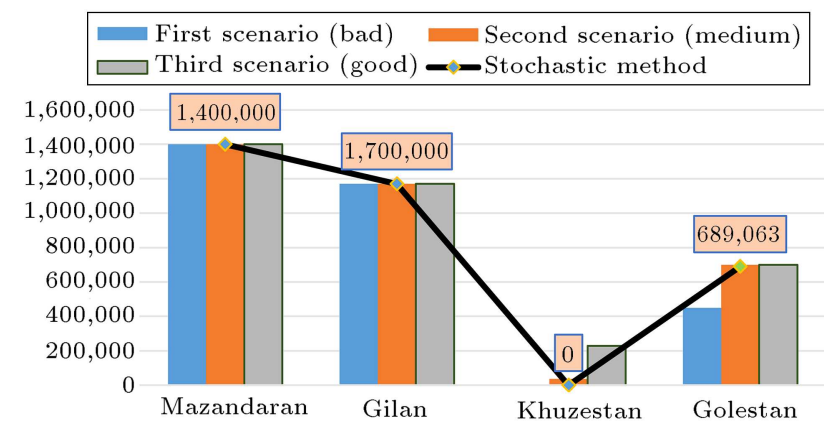

Figure 6. Rice production in each province in different scenarios and stochastic method.

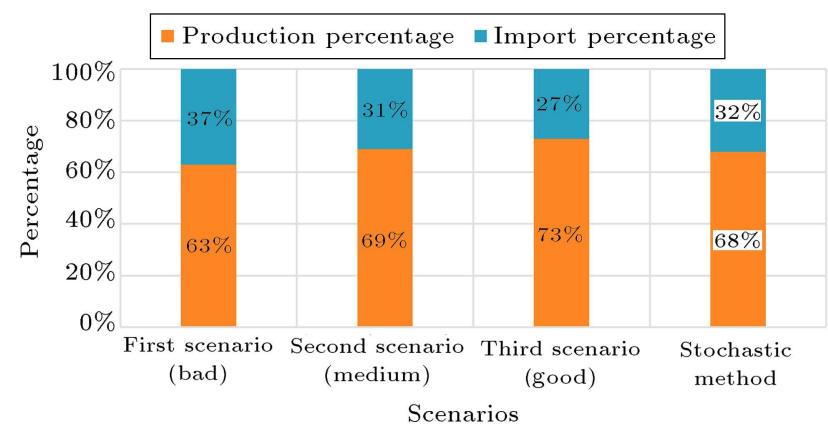

Figure 7. The ratio of demand-supply by import and production in each scenario.

is exactly equal to the average of the scenarios, but this value varies in the case of different numbers of imports. As is known, the amount of production is directly related to the weather conditions of that year (rainfall). Stochastic planning has shown that lack of production in Khuzestan province is not economical at all due to the use of excessive resources.

The next sensitivity analysis is carried out on the significance of the objective functions in the model. The first objective function seeks to minimize the total costs while the second one attempts to minimize the environmental impacts. According to the state of the country in terms of climate, as well as governmental policies, the importance of functions can change. As stated in the previous sections, the first objective function is weighted at 0.7 and the second objective function is 0.3 . However, in Table 13, different states of importance degree for the objective functions are given. This significance degree is determined using the goal programming method, and the same $u$ and $v$ of the intended purpose of the goal programming are expanded.

As shown in Table 13, the economic and environmental dimension of the model has a direct impact on the production and import volume to meet community demand. Given that the economic aspect of the model gains greater significance, the scope of production increases, which is due to high import costs. Whether this amount be lower or not and the importance of environmental impacts be added or not, the amount of production is reduced due to the mentioned damage. For example, in the first row of Table 13, the significance of the economic objective function is set at $90 \%$, and with this condition, the amount of internal production reaches $72 \%$, which results in excessive environmental degradation, and the amount of the environmental

Table 13. Sensitivity analysis based on the importance of objective functions.

\begin{tabular}{|c|c|c|c|c|c|c|c|c|c|c|}
\hline \multirow{2}{*}{$\begin{array}{c}\text { The importance } \\
\text { of functions } \\
(u, v)\end{array}$} & \multirow{2}{*}{$\begin{array}{l}\text { Production } \\
\text { percentage }\end{array}$} & \multirow[t]{2}{*}{$\begin{array}{c}\text { Import } \\
\text { percentage }\end{array}$} & \multirow{2}{*}{$\begin{array}{c}\text { First } \\
\text { objective } \\
\text { function } \\
\left(Z_{1}\right)\end{array}$} & \multirow{2}{*}{$\begin{array}{c}\text { Second } \\
\text { objective } \\
\text { function } \\
\left(Z_{2}\right)\end{array}$} & \multicolumn{2}{|c|}{$\begin{array}{c}\text { Percentage } \\
\text { deviation from }\end{array}$} & \multicolumn{4}{|c|}{$\begin{array}{l}\text { The amount of unhusked } \\
\text { rice production }\end{array}$} \\
\hline & & & & & $b_{1}$ & $b_{2}$ & Mazandaran & Gilan & Khuzestan & Golestan \\
\hline$(0.9,0.1)$ & $72 \%$ & $28 \%$ & $4,948,187,000$ & 6.9 & $8 \%$ & $72 \%$ & $1,400,000$ & $1,170,000$ & 220,000 & 700,000 \\
\hline$(0.8,0.2)$ & $70 \%$ & $30 \%$ & $5,105,846,000$ & 5.84 & $11 \%$ & $45 \%$ & $1,400,000$ & $1,170,000$ & 53,000 & 700,000 \\
\hline$(0.7,0.3)$ & $68 \%$ & $32 \%$ & $5,290,869,000$ & 4.61 & $15 \%$ & $15 \%$ & $1,400,000$ & $1,170,000$ & 0 & 689,063 \\
\hline$(0.6,0.4)$ & $68 \%$ & $32 \%$ & $5,290,869,000$ & 4.61 & $15 \%$ & $15 \%$ & $1,400,000$ & $1,170,000$ & 0 & 689,063 \\
\hline$(0.5,0.5)$ & $63 \%$ & $\% 37$ & $5,592,069,000$ & 4.005 & $22 \%$ & 0 & $1,400,000$ & $1,170,000$ & 0 & 449,446 \\
\hline$(0.4,0.6)$ & $64 \%$ & $36 \%$ & $5,592,064,000$ & 4.005 & $22 \%$ & 0 & $1,400,000$ & $1,170,000$ & 0 & 460,740 \\
\hline$(0.3,0.7)$ & $64 \%$ & $36 \%$ & $5,592,064,000$ & 4.005 & $22 \%$ & 0 & $1,400,000$ & $1,170,000$ & 0 & 460,740 \\
\hline$(0.2,0.8)$ & $64 \%$ & $36 \%$ & $5,592,064,000$ & 4.005 & $22 \%$ & 0 & $1,400,000$ & $1,170,000$ & 0 & 460,740 \\
\hline
\end{tabular}




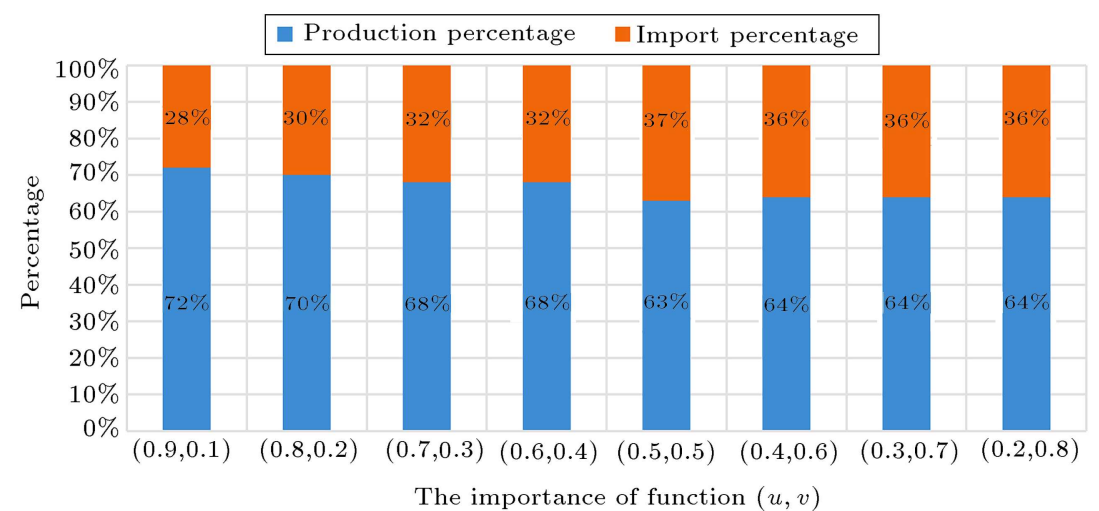

Figure 8. The ratio of demand-supply by import and production according to the importance of objective functions.

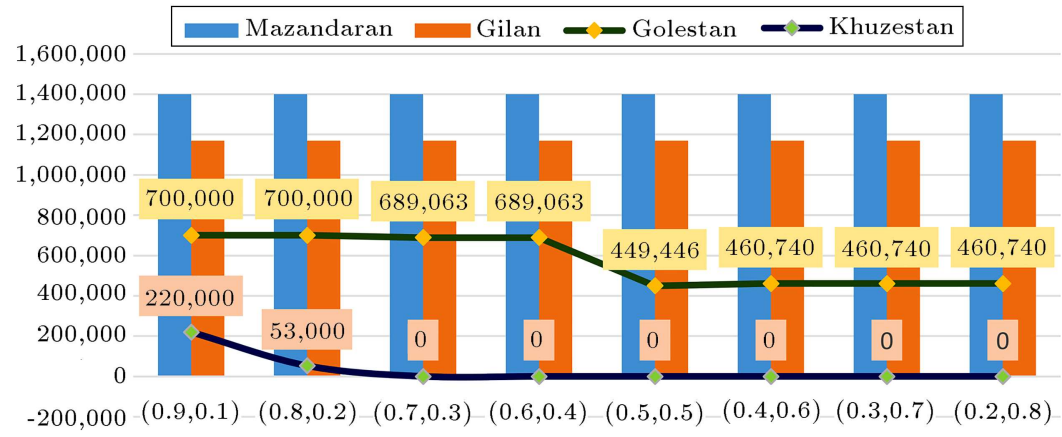

Figure 9. The amount of rice production in each province according to the importance of objective functions.

objective's diversion reaches about $72 \%$. Whether this amount be lower or not, the amount of diversion of the environmental objective function has decreased. Figure 8 illustrates the impact of the production and import ratio that varies according to the importance level of the environmental and economic objectives. As mentioned in the previous sections, the provinces of Gilan and Mazandaran have special climatic conditions as well as the main rice production centers. Therefore, the amount of production in Golestan and Khuzestan provinces due to weather conditions is much weaker than the previous two provinces and their production is subject to variations considering the importance of different functions. For a better understanding, Figure 9 shows that the production of these provinces in any situation is the same as their maximum capacity.

Based on governmental policies, the third sensitivity analysis is related to the amount of imported rice from foreign countries. About $40 \%$ of the country's demand in normal conditions is imported, according to the rice import regulations. This is the maximum allowed import limit for rice. This parameter has a straightforward relationship with the rice price and production volume, as well. Table 14 demonstrates seven different amounts of allowed import limit for the model. In case this value is decreasing, the amount of

Table 14. Sensitivity analysis on import volume.

\begin{tabular}{|c|c|c|c|c|c|c|c|c|c|c|}
\hline \multirow{2}{*}{$\begin{array}{c}\text { Maximum } \\
\text { import } \\
\text { rate }\end{array}$} & \multirow{2}{*}{$\begin{array}{c}\text { Production } \\
\text { ratio }\end{array}$} & \multirow{2}{*}{$\begin{array}{l}\text { Import } \\
\text { ratio }\end{array}$} & \multirow{2}{*}{$\begin{array}{c}\text { Objective } \\
\text { function } \\
Z_{1}\end{array}$} & \multirow{2}{*}{$\begin{array}{c}\text { Objective } \\
\text { function } \\
Z_{2}\end{array}$} & \multirow{2}{*}{$\begin{array}{c}\text { Percentage } \\
\text { deviation } \\
\text { of } b_{1}\end{array}$} & \multirow{2}{*}{$\begin{array}{c}\text { Percentage } \\
\text { deviation } \\
\text { of } b_{2}\end{array}$} & \multicolumn{4}{|c|}{$\begin{array}{c}\text { The amount of unhusked } \\
\text { rice production }\end{array}$} \\
\hline & & & & & & & Mazandaran & Gilan & Khuzestan & Golestan \\
\hline $\begin{array}{c}45 \% \\
\text { and more }\end{array}$ & $68 \%$ & $32 \%$ & $5,290,869,000$ & 4.61 & $15 \%$ & $15 \%$ & $1,400,000$ & $1,170,000$ & 0 & 689,063 \\
\hline $40 \%$ & $68 \%$ & $32 \%$ & $5,290,869,000$ & 4.61 & $15 \%$ & $15 \%$ & $1,400,000$ & $1,170,000$ & 0 & 689,063 \\
\hline $35 \%$ & $69 \%$ & $31 \%$ & $5,105,846,000$ & 5.84 & $12 \%$ & $45 \%$ & $1,400,000$ & $1,170,000$ & 36,991 & 700,000 \\
\hline $30 \%$ & $70 \%$ & $30 \%$ & $5,105,846,000$ & 5.84 & $11 \%$ & $45 \%$ & $1,400,000$ & $1,170,000$ & 53,000 & 700,000 \\
\hline $27 \%$ & $73 \%$ & $27 \%$ & $4,867,175,000$ & 7.46 & $6 \%$ & $86 \%$ & $1,400,000$ & $1,170,000$ & 228,700 & 700,000 \\
\hline $25 \%$ & $75 \%$ & $25 \%$ & $4,698,847,000$ & 8.65 & $2.6 \%$ & $116 \%$ & $1,400,000$ & $1,170,000$ & 324,555 & 700,000 \\
\hline $24 \%$ & $76 \%$ & $24 \%$ & $4,621,691,000$ & 9.25 & $0.9 \%$ & $131 \%$ & $1,400,000$ & $1,170,000$ & 372,482 & 700,000 \\
\hline $\begin{array}{c}23 \% \\
\text { and less }\end{array}$ & \multicolumn{10}{|c|}{ Infeasible } \\
\hline
\end{tabular}




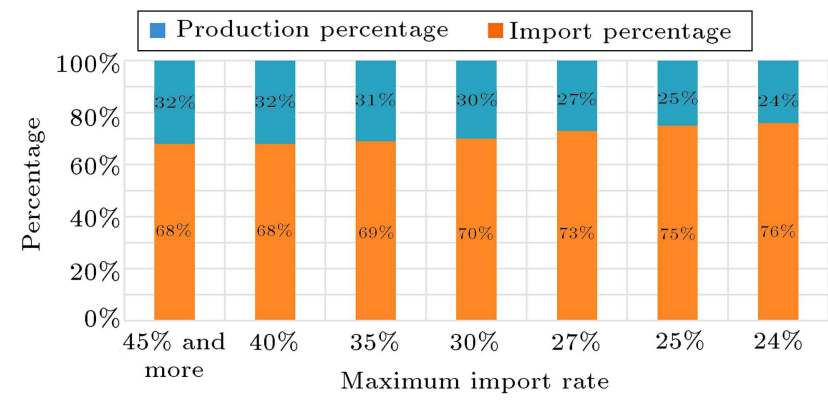

Figure 10. Percentage of demand-supply by import and production with different amounts of allowed import.

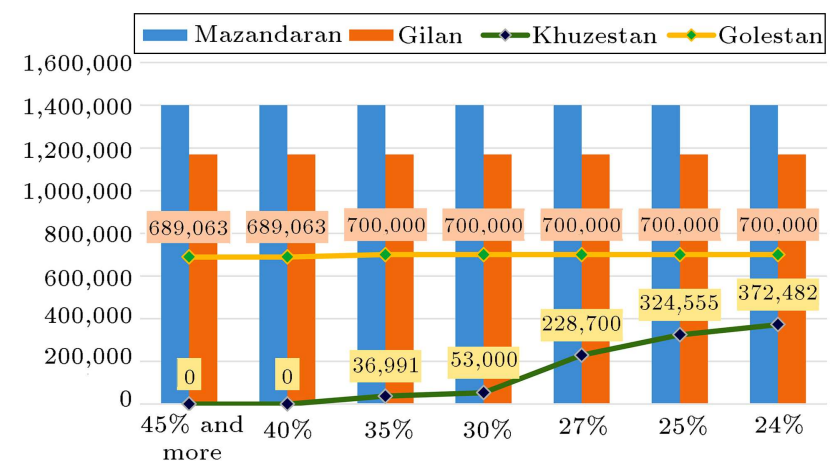

Figure 11. The amount of province production according to different import rates.

produced rice increases to meet the demand. Moreover, import costs are reduced, which in turn reduces the first objective function. On the other hand, the value of the second objective function increases due to the use of its internal capacity. Also, from this table, we find that the permissible values are more than $45 \%$ for the import rate; the number of products, costs, and environmental effects are the same; and rates of less than $23 \%$ make the model impossible. Figure 10 shows the percentage of rice import and production to meet the demand of the community according to the allowed import volume. Figure 11 shows different amounts of rice production in different provinces according to the allowable import rate. For example, the lower the import rate, the higher the production in Khuzestan and Golestan provinces. Eventually, this amount reaches 372,482 and 700,000 tons, respectively.

\section{Managerial suggestions}

The purpose of this article is to achieve the optimal amount of rice production and supply to meet the demand of people in the community while considering the least environmental damage. Besides, the proposed model can help managers make strategic decisions. Studies have shown that Iran can establish itself as one of the top rice producers in the world due to its potential in the field of agriculture, both in terms of climate and production technology. Due to population growth and increased demand in the country, if this issue is not given special attention, it can cause many problems later. Negligence in this regard causes great damage to the country and the people of the society. In the following, some management suggestions are presented to improve the agricultural supply chain, especially rice cultivation in Iran:

1. Special attention to, besides government's support for, the agricultural sector creates prosperity and, more importantly, motivates farmers. This ensures the higher quality of rice products;

2. Appropriate management solutions are considered in cases when the country suffers from acute problems like war or death due to disease and economic sanctions. Recently, with the spread of Coronavirus, a major problem has emerged in the agricultural sector. This means that in the agricultural chain, we must always have a correct forecast at disposal and, in some cases, even more than the calculated amount of demand in the country;

3. Accurate rice consumption per capita can be achieved with the coordination of the provincial governments in the country. By having the exact coefficient of rice consumption at hand, the real demand can be determined and as a result, planning can be done accordingly;

4. One of the factors that can reduce the damage caused by environmental factors is the type of WATERING systems. Optimal use of water resources can increase the life of agricultural land and its soil quality. The right decisions of managers and training of farmers can be a useful way to achieve this importance;

5. Unfortunately, one of the main reasons why Iranian rice has not been introduced in the world remains inadequate advertising or marketing. Participating in international agricultural fairs can be one of the best ways to promote this product;

6. Holding frequent meetings with farmers can be mutually beneficial. Examining existing problems as well as articulating goals can be a good way to increase productivity.

\section{Conclusion}

Rice is one of the most important crops that plays a key role in providing the main food to more than half of the people in the world. In addition to its importance in the food chain, the countries that produce this product can help improve their economic growth, given its high consumption and being on the main household shopping list. This research aimed to design a rice supply chain under uncertainty. In 
this study, a mathematical bi-objective model was applied to provide rice for the country. It included both the environmental and economic impacts of this chain. In the proposed model, uncertain conditions were handled by stochastic programming and extended goal programming. Moreover, our proposed case study in Iran had four rice producers and the country's demand for both production and imports was considered to validate the model viability. Each province was considered a market district, whereas demand was supplied in two ways directly from rice mills with a specific coefficient and distribution centers. Distribution centers also supply rice from imported rice mills and centers. According to the second objective function of the problem, namely water shortages and environmental impacts, Khuzestan is banned from rice production within production regions. Furthermore, the importance of each objective function is related to rice production in the production area. Finally, several suggestions for future research are listed as follows:

1. The model can be developed to consider new objectives such as the utilization of resources and profits;

2. Considering the rice export sector in the supply chain, the produced rice can be exported to other countries;

3. Demand is estimated according to the population in each market. The demand scenario can make the model more realistic;

4. Considering other uncertain programming methods can extend a robust model.

\section{References}

1. Horrigan, L., Lawrence, R.S., and Walker, P. "How sustainable agriculture can address the environmental and human health harms of industrial agriculture", Environ. Health Perspect., 110(5), pp. 445-456 (2002).

2. Vasileiou, K. and Morris, J. "The sustainability of the supply chain for fresh potatoes in Britain", Supply Chain Manag. An Int. J., 11(4), pp. 317-327 (2006).

3. Borin, P., Claro, D.O., and Pensa, U. "Sustainability indicators: a tool to evaluate and monitor the impacts of agri-chains on sustainability", Framework (2006).

4. Peidro, D., Mula, J., Jiménez, M., et al. "A fuzzy linear programming based approach for tactical supply chain planning in an uncertainty environment", European Journal of Operational Research, 205(1), 6(2), pp. 6580 (2010).

5. Peidro, D., Mula, J., Poler, R., et al. "Fuzzy optimization for supply chain planning under supply, demand and process uncertainties", Fuzzy Sets Syst., 160(18), pp. 2640-2657 (2009).

6. Mangla, S.K., Luthra, S., Rich, N., et al. "Enablers to implement sustainable initiatives in agri-food supply chains", International Journal of Production Economics, 203, pp. 379-393 (2018).

7. Fogel, M.A. "Brain magnetic resonance immediately before surgery in single ventricles and surgical postponement", The Annals of Thoracic Surgery, 98(5), pp. 1693-1698 (2014).

8. Yakovleva, N. "Sustainable benchmarking of supply chains: the case of the food industry", International Journal of Production Research, 50(5), pp. 37-41 (2012).

9. Banasik, A., Kanellopoulos, A., Claassen, G.D.H., et al. "Closing loops in agricultural supply chains using multi-objective optimization: A case study of an industrial mushroom supply chain", International Journal of Production Economics, 183, pp. 409-420 (2017).

10. Faulin, J., Juan, A., Lera, F., et al. "Solving the capacitated vehicle routing problem with environmental criteria based on real estimations in road transportation: A case study", Procedia Social and Behavioral Sciences, 20, pp. 323-334 (2011).

11. Banasik, A., Kanellopoulos, A., Claassen, G.D.H., et al. "Closing loops in agricultural supply chains using multi-objective optimization: A case study of an industrial mushroom supply chain", International Journal of Production Economics, 183, pp. 409-420 (2017).

12. Wiedenmann, S. and Geldermann, J. "Supply planning for processors of agricultural raw materials", European Journal of Operational Research, 242(2), pp. 606-619 (2015).

13. Higgins, A.J., Miller, C.J., Archer, A.A., et al. "Challenges of operations research practice in agricultural value chains", J. Oper. Res. Soc., 61(6), pp. 964-973 (2010).

14. Stefansdottir, B. and Grunow, M. "Selecting new product designs and processing technologies under uncertainty: Two-stage stochastic model and application to a food supply chain", International Journal of Production Economics, 201, pp. 89-101 (2018).

15. Mangla, S.K., Luthra, S., Rich, N., et al. "Enablers to implement sustainable initiatives in agri-food supply chains", International Journal of Production Economics, 203, pp. 379-393 (2018).

16. Van Der Vorst, J.G.A.J., Tromp, S.O., and van der Zee, D.J. "Simulation modelling for food supply chain redesign; integrated decision making on product quality, sustainability and logistics", International Journal of Production Research. J. Prod. Res., 47(23), pp. 6611-6631 (2009).

17. Sorensen, E.E. and Gilheany, J.F. "A simulation model for harvest operations under stochastic conditions", Manage. Sci., 16(8), pp. B-549-B-565 (1970).

18. Arnaout, J.-P.M. and Maatouk, M. "Optimization of quality and operational costs through improved scheduling of harvest operations", International Transactions in Operational Research, 17(5), pp. 595-605 (2010). 
19. Gorton, M., Zari, V., Lowe, P., et al. "Public and private agri-environmental regulation in post-socialist economies: Evidence from the Serbian Fresh Fruit and Vegetable Sector", Journal of Rural Studies, 27, pp. 144-152 (2011).

20. Masud, M.B., McAllister, T., Cordeiro, M.R.C., et al. "Modeling future water footprint of barley production in Alberta, Canada: Implications for water use and yields to 2064", Science of the Total Environment, 616-617, pp. 208-222 (2018).

21. Su, C.M., Horng, D.J., Tseng, M.L., et al. "Improving sustainable supply chain management using a novel hierarchical grey-DEMATEL approach", Journal of Cleaner Production, 134, pp. 469-481 (2016).

22. Sepehri, M. and Sazvar, Z. "Multi-objective sustainable supply chain with deteriorating products and transportation options under uncertain demand and backorder", Journal of Scientia Iranica, Sharif University of Technology, 23(6), pp. 2977-2994 (2016).

23. Jafari, H.R., Seifbarghy, M., and Omidvari, M. "Sustainable supply chain design with water environmental impacts and justice-oriented employment considerations: A case study in textile industry", Journal of Scientia Iranica, Sharif University of Technology Trans. E, Ind. Eng., 24(4), pp. 2119-2137 (2017).

24. Reidsma, P., Janssen, S., Jansen, J., et al. "On the development and use of farm models for policy impact assessment in the European Union-A review", Journal of Agricultural Systems, 159, pp. 111-125 (2018).

25. Mohammadi, A.S., Alemtabriz, A., Pishvaee, M.S., et al. "A multi-stage stochastic programming model for sustainable closed-loop supply chain network design with financial decisions: A case study of plastic production and recycling supply chain", Journal of Scientia Iranica, Sharif University of Technology, 27(1), pp. 377-395 (2020).

26. Sazvar, Z., Rahmani, M., and Govindan, K. "A sustainable supply chain for organic, conventional agro-food products: The role of demand substitution, climate change and public health", Journal of Cleaner Production, 194(1) (2018).

27. Mogale, D.G., Cheikhrouhou, N., and Tiwari, M.K. "Modelling of sustainable food grain supply chain distribution system: a bi-objective approach", International Journal of Production Research, 58(18), pp. 5521-5544 (2020).

28. Yamchi, H., Jabarzadeh, Y., Ghaffarinasab, N., et al. "A multi-objective linear optimization model for designing sustainable closed-loop agricultural supply chain", Proceedings of the 10th Conference on Industrial Engineering and Operations Management (IEOM) (2020).

29. Motevalli-Taher, F., Paydar, M.M., and Emami, S. "Wheat sustainable supply chain network design with forecasted demand by simulation", Computers and Electronics in Agriculture, 178, p. 105763 (2020).
30. Jia, R., Liu, Y., and Bai, X. "Distributionally robust goal programming approach for planning a sustainable development problem", Journal of Cleaner Production, 256, p. 120438 (2020).

31. Borodin, V., Bourtembourg, J., Hnaien, F., et al. "A quality risk management problem: case of annual crop harvest scheduling", International Journal of Production Research, 52(9), pp. 2682-2695 (2014).

32. Yoshimoto, A. and Shoji, I. "Searching for an optimal rotation age for forest stand management under stochastic log prices", European Journal of Operational Research, 105(1), pp. 100-112 (1998).

33. Romero, C. "A general structure of achievement function for a goal programming model", European Journal of Operational Research, 153(3), SPEC. ISS., pp. 675686 (2003).

34. Gendreau, M. and Potvin, J.Y., Handbook of Metaheuristics, New York: Springer, 2 (2010).

35. Chen, W., Li, J., and Jin, X. "The replenishment policy of agri-products with stochastic demand in integrated agricultural supply chains", Expert Systems with Applications, 48(1) (2015).

36. Etemadnia, H., Goetz, S.J., Canning, P., et al. "PT US CR", European Journal of Operational Research, $\mathbf{2 4 4}(2)$ (2015).

37. Hajikhani, A., Khalilzadeh, M., and Sadjadi, S.J. "A fuzzy multi-objective multi-product supplier selection and order-allocation problem in supply chain under coverage and price considerations: An urban agricultural case study", Journal of Scientia Iranica Sharif University of Technology, Trans. E, Ind. Eng., 25(1), pp. 431-449 (2018).

38. Catalá, L.P., Moreno, M.S., Blanco, A.M., et al. "A biobjective optimization model for tactical planning in the pome fruit industry supply chain", Computers and Electronics in Agriculture, 130, pp. 128-141 (2016).

39. Galán-Martín, Á., Vaskan, P., Antón, A., et al. "Multiobjective optimization of rainfed and irrigated agricultural areas considering production and environmental criteria: a case study of wheat production in Spain", Journal of Cleaner Production, 140, pp. 816-830 (2017).

40. Gomes, A.C., Pinto-Varela, T., and Barbosa-Póvoa, A.P. "Multimodal green food supply chain design and planning under uncertainty", In Computer Aided Chemical Engineering, 38, pp. 181-186 (2016).

41. Soto-silva, W.E., González-araya, M.C., OlivaFernández, M.A., et al. "Optimizing fresh food logistics for processing: Application for a large Chilean apple supply chain", Computers and Electronics in Agriculture, 136, pp. 42-57 (2017).

42. Tian, G., Zhang, H., Feng, Y., et al. "Green decoration materials selection under interior environment characteristics: A grey-correlation based hybrid MCDM method", Renewable and Sustainable Energy Reviews, 816, pp. 682-692 (2018). 
43. Cheraghalipour, A., Paydar, M.M., and HajiaghaeiKeshteli, M. "A bi-objective optimization for citrus closed-loop supply chain using Pareto-based algorithms", Applied Soft Computing, 69, pp. 33-59 (2018).

44. Chávez, M.M.M., Sarache, W., and Costa, Y. "Towards a comprehensive model of a biofuel supply chain optimization from coffee crop residues", Transportation Research Part E: Logistics and Transportation Review, 116, pp. 136-162 (2018).

45. Allaoui, H., Guo, Y., Choudhary, A., et al. "Sustainable agro-food supply chain design using two-stage hybrid multi-objective decision-making approach", Computers \& Operations Research (2016).

46. Bergendahl, J.A., Sarkis, J., and Timko, M.T. "Transdisciplinarity and the food energy and water nexus: Ecological modernization and supply chain sustainability perspectives", Resources, Conservation and Recycling, 133, pp. 309-319 (2018).

47. Cheraghalipour, A., Paydar, M.M., and HajiaghaeiKeshteli, M. "Designing and solving a bi-level model for rice supply chain using the evolutionary algorithms", Computers and Electronics in Agriculture, 162, pp. 651-668 (2019).

48. Lin, R., Man, Y., Lee, C.K.M., et al. "Sustainability prioritization framework of biorefinery: A novel multi-criteria decision-making model under uncertainty based on an improved interval goal programming method", Journal of Cleaner Production, 251, p. 119729 (2020).

49. Chávez, M.M.M., Sarache, W., Costa, Y., et al. "Multiobjective stochastic scheduling of upstream operations in a sustainable sugarcane supply chain", Journal of Cleaner Production, 276, p. 123305 (2020).

50. Roghanian, E. and Cheraghalipour, A. "Addressing a set of meta-heuristics to solve a multi-objective model for closed-loop citrus supply chain considering $\mathrm{CO}_{2}$ emissions", Journal of Cleaner Production, 239, p. 118081 (Dec. 2019).

51. Seyyed Jifroudi, S.A., Teimoury, E., and Barzinpour, F. "Designing and planning a rice supply chain: a case study for Iran farmlands", Decision Science Letters, 9(2), pp. 163-180 (2020).

52. Hosseini-Motlagh, S.M., Samani, M.R.G., and Saadi, F.A. "A novel hybrid approach for synchronized development of sustainability and resiliency in the wheat network", Computers and Electronics in Agriculture, 168, p. 105095 (Jan. 2020).

53. Biuki, M., Kazemi, A., and Alinezhad, A. "An integrated location-routing-inventory model for sustainable design of a perishable products supply chain network", Journal of Cleaner Production, 260(1), p. 120842 (2020).
54. Jabarzadeh, Y., Yamchi, H.R., Kumar, V., et al. "A multi-objective mixed-integer linear model for sustainable fruit closed-loop supply chain network", Management of Environmental Quality An International Journal, 31(5) (2020).

55. Mehrbanfar, M., Bozorgi-Amiri, A., and Nasiri, M.M. "A mathematical programming model for sustainable agricultural supply chain network design under uncertainty", Journal of Quality Engineering and Production Optimization (2020).

56. Sahebjamnia, N., Goodarzian, F., and HajiaghaeiKeshteli, M. "Optimization of multi-period threeechelon citrus supply chain problem", Journal of $O p$ timization in Industrial Engineering, 13(1), pp. 39-53 (2020).

\section{Biographies}

Mohammad Jalal Kazemi received his MSc in Industrial Engineering from the Babol Noshirvani University of Technology, in Babol, Iran. His research interests include agricultural supply chain, sustainability in the supply chain, and stochastic programming.

Mohammad Mahdi Paydar is an Associate Professor at the Department of Industrial Engineering at Babol Noshirvani University of Technology, Babol, Iran. He received his $\mathrm{PhD}$ in Industrial Engineering from Iran University of Science and Technology in 2014. His research interests include supply chain design, applied operations research, multi-objective optimization, and cellular manufacturing. He has published more than 90 papers in international journals and conferences including Tourism Management, Expert Systems with Applications, Computers \& Operations Research, Journal of Cleaner Production, Computers \& Industrial Engineering, Knowledge-Based Systems, Scientia Iranica, Applied Mathematical Modelling, etc.

Abdul Sattar Safaei is an Associate Professor of Industrial Engineering at the Babol Noshirvani University of Technology. He received his $\mathrm{PhD}$ in Industrial Engineering from Tarbiat Modares University in 2012 and obtained his MS and BS both in the same field from the Amirkabir University of Technology in 2007 and K. N. Toosi University of Technology in 2004, respectively. His main research interests are purchasing management, strategic planning, sustainable logistics, and Agri supply chain optimization. He has published articles in such journals as Applied Mathematical Modelling, International Journal of Advanced Manufacturing Technology, International Journal of Production Research, Computers and Chemical Engineering, and Waste Management. 